Ankara Üniversitesi Türk İnkllâp Tarihi Enstitüsü Atatürk Yolu Dergisi S 41, Mayıs 2008, s. 17-34

\title{
Mütareke Dönemi Asayişin Üç Boyutu
}

\section{Yrd. Doç. Dr. İhsan Sabri BALKAYA* ÖZET}

30 Ekim 1918'de Mondros Mütarekesi'nin imzalanmastyla dört yıl süren Birinci Dünya Savaşı bitmiştir. Böylece Osmanlı Devleti ve Türk Milleti için mütareke dönemi başlanmıştır. Bu dönemde Türk milletinin vatanı ve bă̆ımsızlığ elinden alınmaya başlamıştır. Yaşanan işgaller ve çetecilik faaliyetleri ile; canmal ve namus güvenliği ortadan kalkmış ve bu durum asayiş kavramı ile ifade edilmiştir.

Asayiş kavramı bu dönem üç boyutlu bir şekilde ele alınıp, değerlendirilip,gereği yapılmıștır. Mütareke dönemi asayişin birinci boyutunda İstanbul hükümetleri, ikinci boyutunda İtilaf Devletleri, üz̧üncü boyutunda Kuvâ-yı Millîye ya da Millî Mücadeleciler yer almıştır. Bu makalede bu üç boyut irdelenmeye çalışılmıştır.

Anahtar Sözcükler: Mütâreke, Asayiş, İstanbul hükümetleri, Millî Mücadele.

\section{Three Dimensions of Order In The Armistice Period}

\section{Abstract}

World War I, which lasted four years, ended when Armistice of Moudros was signed on 30 October, 1918. Hence, the period of Armistice started for the Ottoman Empire and Turkish Nation. In this period, the native country and sovereignty of the Turkish Nation has been started to get from the people. Through the occupations and banditry life, property, and honour security disappeared and this situation has been stated with the concept of "order."

In this period, the concept of order has been handled and evaluated with three dimensions. In the first dimension of order concept in the period of Armistice Istanbul governments, in the second dimension Allies, and in the third dimension Turkish revolutionaries and National Strugglers took place. In this article, these three dimensions have been investigated.

Keywords: Armistice, Order, Istanbul Governments, Turkish National Struggle.

• Atatürk Üniversitesi Kâzım Karabekir Eğitim Fakültesi Ilkögretim Bölümü Sosyal Bilgiler ABD,Erzurum, balkaya@atauni.edu.tr 


\section{GíRIŞ}

Savaşlar, her zaman ülke ve milletlerin hayatında çok ciddî, beklenmedik olağanüstü hadiselerin yaşanmasına sebep olmuştur. Hatta bu durumların etkileri, savaş sonrasında da devam etmiştir. Birinci Dünya Harbi de Türk milleti için aynı özellikleri içerisinde taşımış, hatta beklenmedik bir sürecin de sebebi olmuştur. Savaşı sona erdiren Mondros Mütarekesinin 30 Ekim 1918'de imzalanması ile Türk tarihinde yeni bir dönem ve süreç böylece başlamıştır. Dört yıl süren Birinci Dünya Harbinin bitmesiyle Türk halkı savaşsız ve acısız bir dönemin başlayacağı ümidi içerisine girmiştir. Ama ne yazık ki gelişmeler, Türk insanının bu ümidini boşa çıkarmıştır.

Mondros Mütarekesi Türk milleti için, bağımsızlığı başta olmak üzere, işgallerle vatanının, can, mal ve namusunun kısaca her şeyinin elinden alındığı bir dönemi de başlatmıştır. Bütün bu beklenmedik veya en azından halk nazarında beklenilmeyen olaylar kısa bir süre içerisinde yurdun dört bir tarafında yaşanmaya başlanmıştır.

Osmanlı Devleti, Birinci Dünya Savaşı süresince, otorite boşluğundan ve aynı zamanda savaş ortamından kaynaklanan, asayiş ve düzenin sağlanması ile ilgili sıkıntılarla karşı karşıya kalmış; Mondros Mütarekesi ile birlikte bu durum kendisini daha da hissettirmiştir. Hükümet yetkilileri savaş süresince almaya çalıştıkları gerekli tedbirleri savaş sonrası da devam ettirmişleridir. Ancak Mütareke ile oldukça farklı bir dönem ve anlayış başlamıştır.

Mondros Mütarekesini imzalayan heyetin başkanı ve aynı zamanda Bahriye Nazırı olan Hüseyin Rauf (Orbay) Bey, İstanbul basınına yapmış olduğu açıklamada Mütarekeden memnuniyetini bildirince, Yeni Gün Gazetesi yazarının, "Sizi bu derece memnun eden esbab nedir?" sorusuna şu cevabı vermiştir: “....Saniyen memleketimizin zannedildið̌ine muhalif olarak isgal altına alınmayacă̆ını gördüm. Sizi temin ederim ki İstanbul'umuza bir tek düșman askeri çıkmayacaktır. Tabii ki bir kaç zabit şurada burada görülebilecektir...” diyen Rauf Bey sözlerini şöyle tamamlamıştır: "Yalnız şurası mühimdir ki, memleketimizde asayişi muhafaza etmeliyiz. Aksi takdirde her şeyi kaybetme tehlikesi vardır." ${ }^{1}$ $\mathrm{Bu}$ açıklamasıyla $\mathrm{H}$. Rauf Bey böylece birinci ağızdan, yukarıda ifade edilmeye çalışılan farklı bir dönem ve anlayışın sinyallerini vermiş oluyordu. İstanbul kamuoyu böylesine bir maniple ile karşı karşıya kalmıştır. Ülkenin ücra köşelerinin böylesine bir maniple imkânı bile yoktu. Onlar içinde bulundukları durumun vahametini ancak yaşayacakları acı tecrübelerle anlayacaklardı. 10

'. Dr. Salahi R. Sonyel, Türk Kurtuluş Savaşı ve Dış Politika I, Ankara 1995, s. 9- 
Ancak H. Rauf Bey'in açıklamasında oldukça dikkate değer bir değerlendirme ve inanışı görmemek mümkün değildir; o da, ülkede mutlaka asayişin sağlanması gerektiği, aksi taktirde her şeyimizi kaybedeceğimiz tehlikesidir. Yani her şeyimizin garantisi veya sigortası bu üç heceli "Asayiş" kelimesinde gizli olduğudur. Bu. şu anlama geliyordu herhalde; asayiş berkemal ise ülkenin ve milletin hiç bir şeyi kaybetme ihtimali yok; ama asayiş bîkemal ise, ülke ve millet her şeyini kaybetme tehlikesiyle karşı karşıyadır.

O zaman yapılacak tek bir şey var; o da, Osmanlı Devletini idare edenlerin, iktidar sahiplerinin, Mondros Mütarekesinin imzalandığı tarih itibariyle elde kalan topraklar dahilinde rahat, huzur ve güvenliği sağlamak; bunun için her türlü tedbir ve önlemi almaktır. İstanbul hükümetlerinin bu dönemde asayişin sağlanması için ilgili makamlara göndermiş olduğu yazılarda ya da asayişten sorumlu olan güvenlik güçlerinin kendi aralarında yapmış oldukları yazışmalarda hep bu konunun işlendiğini görmek mümkündür. Ancak gelişmeler asayiş konusunda üç farklı boyutun yaşandığını ortaya koymaktadır: Bunlardan birincisi, İstanbul hükümetlerinin asayiş konusunda göstermiş oldukları algılama ve uygulamalar; ikincisi, İtilaf Devletlerinin ve hazırlayıp imzalattırdıkları Mondros Mütarekesinin maddelerinin asayişi etkileme durumu; üçüncüsü, Kuvâ-yı Millîye anlayışının ve örgütlenmesinin asayiş konusundaki yaklaşımıdır. Mütareke döneminde İstanbul Hükümetleri, İtilaf Devletleri ve Mustafa Kemal'in önderliğindeki Millî Mücadele hareketinin yetkili ve sorumlularının asayiş ya da asayişsizliğin ne olduğu konusunda göstermiş oldukları farklı tutum ve yaklaşımlar bu çalışmada irdelenmeye çalışılacaktır.

İlk önce hükümet kanadından başlamak her halde dogru olacaktır. Çünkü asayiş konusunun birinci derecede muhatabı İstanbul Hükümetleri olmuştur.

\section{1. İstanbul Hükümetleri ve Asayişin Birinci Boyutu}

Mondros Mütarekesi imzalanmadan önce Talat Paşa kabinesi istifa etmiş; yerine, Ahmet İzzet Paşa Hükümeti kurulmuştur (14 Ekim-8 Kasım 1918 ). Ahmet İzzet Paşa Hükümeti de Mütarekeyi imzaladıktan sonra $8 \mathrm{Kasım}$ 'da istifa etmiştir. Padişah Vahidettin Ahmet Tevfik Paşa'yı hükümet kurmakla görevlendirmiştir (11 Kasım 1918- 24 Şubat 1919 ). Ahmet Tevfik Paşa hükümetinin istifasından sonra Damat Ferit Paşa Hükümetleri dönemi başlamıştır (4 Mart-15/16 Mayıs 1919, 19 Mayıs- 20 Temmuz 1919, 21 Temmuz-1 Ekim 1919). Damat Ferit'in 1 Ekim 1919'da istifasından sonra Ali Rıza Paşa Hükümeti kurulmuştur (2 Ekim 1919- 3 Mart 1920). Ali Rıza Paşa hükümetinin istifasından sonra Salih Hulusi Paşa (8 Mart- 2 Nisan 1920) tarihleri arasında 
hükümet kurmuştur. Bundan sonra yine Damat Ferit Paşa dönemi başlamıştır (5 Nisan-30 temmuz 1920, 31 Temmuz - 17 Ekim 1920 ). Damat Ferit Paşa hükümetinin istifasından sonra 4 Kasım 1922'ye kadar İstanbul Hükümetinin başında Ahmet Tevfik Paşa bulunmuştur ${ }^{2}$.

Kasım 1918 itibariyle Osmanlı coğrafyasında biten savaşın getirdiği asayişsizlik, sosyal, ekonomik, psikolojik, askerî ve siyasî sıkıntıların Mondros Mütarekesi maddeleriyle katmerleştiği yeni bir zaman diliminin muhatabı, yukarıda sıralanan hükümetler olmuştur. Böylesine hassas bir dönemde bakan değişiklikleri hariç tam on kez hükümet değişikliği yaşanmıştır. Durmadan değişen hükümetlerin ciddi programlarla devlet ve millet meselelerini ele almadıkları gibi, bilhassa Damat Ferit Paşa Hükümetleri yalnız ve yalnız İstanbul'a yerleşen İtilaf Devletlerinin dilek ve arzularını yerine getirme gayreti ile ülke menfaatini koruma gafleti içerisinde olmuşlardır. ${ }^{3}$

Ülke genelinde kanun hakimiyetinin tam manasıyla sağlanamaması, İstanbul ile başlayan işgallerin yurdun her tarafına yayılması, gayrimüslimlerin özellikle Rum ve Ermenilerin kurmuş oldukları örgütlerin kontrolünde silahlı çete eylemlerinin başlaması, bir de bunların yanında o günkü ifadeyle Müslümanların oluşturdukları çetelerin faaliyetleri, asayişi bozan başlıca etkenler olarak ortaya çıkmıştır. Huzur ve güveni sarsan bu eylemleri; yol kesme, gasp, ırza tecavüz, hırsızlık, seyahati engelleme, yakıp yıkma ve benzeri siyasî içerikli olmayan, çetelerin veya bunların mensuplarının girişimleri olarak sınıflandırmak değerlendirmek mümkündür. İstanbul hükümetleri, kanun ve güvenlik güçlerinin zayıflığını fırsat bilerek kendine güç ve otorite oluşturmak isteyenlerin, maceraperestlerin, paraya ve şöhrete zaafiyeti olanların, kişilik bozukluğu olanların, aklî dengesi yerinde olmayanların, fırsatı ganimet bilen kişi ya da kişilerin oluşturmuş oldukları çetelerin, ülkenin her yerinde huzur ve güveni bozucu eylemlerine karşı gerekli önlemleri almaya çalışmışlardır.

Görüldügü gibi İstanbul hükümetleri asayişi bozan iki farklı grupla karşı karşıya kalmıştır; bunlardan birisi gayrimüslimler, diğeri de yerli çetelerdir. Tabii bunlardan birincisi, bir müddet sonra işgal devletlerinin korumasıyla huzuru bozan olmaktan kurtulurken, vatanın ve milletin bağımsızlı̆̆ı için ortaya çıkan Kuvâ-yı Millîye hareketi ve bunların mensupları İstanbul Hükümetleri içerisinde özellikle Damat Ferit Paşa Hükümetleri nazarında asayişi bozan taraf olarak yerini alacaktır.

30 Ekim'de Mütareke imzalandığında 1918 yılının da son iki ayına girilmiştir. Bu iki ay daha çok mütarekeyi imzalayan kabinenin

${ }^{2}$. Zeki Sarhhan, Kurtulus Savaşı Günlü̈̆̈̈ I, Ankara 1993, s.2,21,155-156.

3. Sitkı Aydınel, Güney Batı Anadolu'da Kuvâ-yı Milliye Harekâtı, Ankara 1993, s.41. 
başbakanı Ahmet İzzet Paşa Parlamentoda, Bahriye ve Dışişleri Bakanları basın toplantılarıyla mütarekenin hafif ve mülayimliğinden söz ederek ${ }^{4}$ kamuoyunu teskin etmekle vakit geçirirken, bundan sonraki hükümet İstanbul'a İtilaf Devletlerinin gelip yerleşmesi şokunu atlatmaya çalışarak, onlarla iyi geçinmenin yollarını aramıştır. 1919 yılı ise, işgal ve asayişin en yoğun yaşandığ ${ }_{1}$ yll olurken, bu dönemin, Birinci Damat Ferit Hükümetinin asayişten sorumlu olan İçişleri Bakanı Mehmet Ali Bey, "Bütün Anadolu'da bir kaç şekavet hadisesinden başka asayişsizlik yoktur." "ş̧eklinde gazetelere verdiği demeçle hem itilaf devletlerini, hem de Türk kamuoyunu idare etmeye çalışmıstır.

Oysa her geçen gün asayişle ilgili haberler hükümet merkezini ve yetkilileri altından kalkamayacakları sıkıntılara sokmaya başlamıştır bile. Başta Batı Anadolu olmak üzere durum hiç de iç açıcı değildir. Çoğu asker kaçağı olan Efe ve Zeybek çeteleri, Batı Anadolu'da asayişi çok bozmuştur. Bir kısım zenginler ise mal ve mülklerini korumak için onlara sığınmışlardır. Mevcut jandarma sayı bakımından yeterli değildir. Öylesine azıtmıştır ki bu çeteler; kaza, nahiye ve köyleri basarak dağa adam kaldırmışlardır. Bölge Rumlarına gelince onlar da yerlerinde durmamışlardır. Adalardan kıyı köylerine silahlı olarak çıkmaya başlamış, o kadar ileri gitmişlerdir ki jandarma karakolunu basmış, görevlileri döverek halka teşhir etmişlerdir. Duruma müdahale etmek için harekete geçen askerî kuvvet ise bir İngiliz subayı tarafından engellenmiştir. ${ }^{6}$ İstanbul hükümetleri bütün yazışmalarında; valisinden mutasarrıfına ve askeri yetkililere varan bütün yetkililere işgaller karşında hiçbir girişimde bulunmamayı ögütlerken, vatandaşı da direnişten uzak, sakin ve sessiz olmaya çağırmıştır. Buna en iyi örneklerden biri 15 Haziran 1919 tarihli Dahiliye Nezâretinin Denizli Mutasarrıflığına gönderdiği yazının içeriğidir. Denizli mutasarrıfından; asayişin sağlanması ile Rumların her türlü fesat ve art niyetlerine engel olunacağı, her şeye rağmen açık ve anlaşılır bir şekilde iyi niyetli olmaları, Müslüman halkı haksız yere öldürmeyi ve Yunanlılara gereksiz yere harp ve saldırıya sebep kılmamayı unutmamaları, son bir çağrı ile; hükümetin barış konferansında hak ve hukukumuzu var gücüyle savunduğu hayırlı bir neticenin alınacağının aşikar olduğu, bunun için huzur ve asayişin sağlamaları özellikle vurgulanmıştır.

Yine aynı içerikli bir başka yazı da Antalya Mutasarrıflığına gönderilmiştir. Orada da hak ve hukukumuzun barış konferansında elde

${ }^{4}$. Gotthard Jaescke, Kurtulus Savaşı İle İlgili İngiliz Belgeleri, Ankara 1991, s. 27.

5. Gorthard Jaeschke, Türk Kurtuluş Savaşı Kronolojisi - Mondros'tan Mudanya'ya Kadar, Ankara 1989,s.27.

. Rahmi Apak, Istiklâl Savaşında Garp Cephesi Nasıl Kuruldu, .Ankara 1990, s.75.

7. BOA, DH.ŞFR, 337 N 16. $100 / 109$. 
edilmeye çalışılacağı, açık ve seçik olan hakkımızın medeni devletlerce gaspçılara çiğnetilirse konferanstan sonra Türklük ve Osmanlılık adına yapılması gerekenin düşünülüp yapılacağı söylenmiştir. Son olarak siyasî olarak son ümitlerin yok edilmemesi için sorumlulukları gereği en büyük vazifenin heyecanlı olan halkı sakinleştirmek, huzur ve güveni bozucu girişimlere karşı kesin tedbirler alarak asayişin bozulmasına izin vermemek olduğu yazılmıştır. ${ }^{8}$

Aynı içerikte belgeleri çoğaltmak mümkündür. $\mathrm{Bu}$ anlamda yazışmalar İstanbul Hükümetlerinin İşgalci Devletlerin askeri güçlerinin ve onlardan destek alan gayrimüslimlerin yapıp ettiklerinden ziyade, asayişi sağlama noktasında yetkililerden ülke insanın kontrol altında tutulmasını istemeleri, bir asayiş algılama yanılgısı ve çözümüne yönelik ciddi bir stratejik hatanın yapıldı̆̆ıdır. Yani amandır işgal devletlerini kızdırmayalım, bizim çetelerin başını ezelim, gayet haklı bir şekilde ayăga kalkmış halkı da sakinleştirelim yoksa daha kötü bir gelecekle karşı karşıya kalırız anlayışı ile hükümet etme tavrı sergilenmiştir. Hatta Anadolu ve Rumeli'ye nasihat heyetleri gönderilmiştir. İlk önce Rum eşkıyalarını yola getirmek amacıyla kurulan bu heyetler daha sonra daha esaslı ve daha kapsamlı olarak düzenlenmiştir. Ülkenin en temiz ve sevilen şahsiyetlerinden oluşan nasihat heyetleri; Anadolu'nun çeşitli yerlerini dolaşarak halkı ziyaret edip, halkı sükunete davet ederek gayrimüslimlerle iyi geçinmelerini isterken asıl amaç hükümetin alacağı kararlara itaatlerini sağlamak olmuştur.'

Tam bu noktada İstanbul'daki İtilaf Devletleri yetkilileri, Osmanlı Hükümetlerini Müslüman halkın asayiş ve huzuru bozucu eylemler içerisinde oldukları şikâyetleri ile baskı altına almaya çalışılarak, kontrol ve denetimlerini sağlamlaştırma fırsatını yakalamışlardır. Gerek işgalci devletlerin asayiş konusundaki tarafgirlikleri, gerekse Osmanlı Hükümetlerinin asayiş konusunda onları incitmemeye çalışmaları, Türk bağımsızlık mücadelesinin önderine kavuşmasına giden yolu aralamıştır.

Mustafa Kemal Samsun'a işte böylesi bir asayiş sorununun yoğunluğu içerisinde gönderilmiştir. Mustafa Kemal Samsun'da Dokuzuncu Ordu Müfettişi olarak geniş yetkilerle görevine başlamıştır. Askerî ve sivil yetkililerle yapmış olduğu yazışmalarla sorumluluk alanındaki asayiş sorununu anlamaya çalışarak, gerekli tedbirlerin alınması için lazım gelen emirleri vermiştir. Gelişmeleri hem İstanbul'dan aldığ ${ }_{1}$ hem de sorumluluk bölgesindeki yetkililerden aldığ bilgilerle takip etmiştir. Siyasi içerikli olmayan eşkıya hareketlerinin

${ }^{8}$. BOA. DH.ŞFR, 337 N 19, $100 / 148$.

9. Tayip Gökbilgin, Millî Mücadele Başlarken, Ankara 1959, s. 64-66. 
önlenmesi için her türlü tedbir alınmıştır. ${ }^{10}$ Yani İngiliz General Calthorpe'nin 21 Nisan 1919 tarihli İstanbul hükümetine vermiş olduğu notada belirttiği gibi; bölgede Rum yaygarasına dayanan, Rumların karşı karşıya kaldıkları katliam iddialarının ${ }^{11}$ doğru olmadığı, Türk halkının nefsi müdafaa içerisinde olduğu anlaşılmıştır. Ama bunu, işgalci devlet yetkililerine ya da onların bir dediğini ikilemeyen Damat Ferit Hükümetlerine kabul ettirmek mümkün olmamıştır.

Damat Ferit Paşa Hükümetlerinin asayiş konusundaki bir diğer algılama boyutu ise; vatan topraklarının işgal edilmesi karşısında Türk insanının kendi doğal refleksi olarak doğan Kuvâ-yı Millîye hareketini, bu örgütlenme içerisinde oluşan silahlı halkın işgallere karşı yapmış olduğu engelleme ve savunma girişimlerini asayişi bozan hareket olarak görmesidir. İstanbul Hükümetinin bu tavrını 17 Haziran tarihli Meclis-i Vükelâ kararıyla vilâyetlere ve müstakil sancaklara Dahiliye Nazırı Ali Kemal Bey tarafından gönderilen şu tamim çok iyi yansıtmaktadır: “ ...Işgallerden ne derece müteessir olursa ve münfail olursa olsun Osmanlı Hükûmeti bu siralarda harb ve darba tutuşamaz çünkü bu gün varlığını ancak siyaseten müdafaa edebilir bir vaziyettedir... Murahhaslarımızın böylece vatanın asıl parçalarını kurtaracaklarına ümidimiz günden güne artmaktadır. Bu vaziyeti gücleştirecek ve hattâ imkansız hale kllacak bir felâket için bilhassa dikkat nazarınızı ve hamiyetinizi celbederim. O felâkette Millî ordu teşkil etmek, millı̂ müdafaay hazırlamak gibi endişelerle şu sıralarda son derece muhtacı olduğumuz memleket asayişini bozmak ve unsurlar arasında düşmanlı̆̆ yeniden fiilen uyandırarak memleketimizdeki İtilâf mümessillerinin hoşnutsuzluğunu celbetmek, kanunsuzluk, şekavet, yă̆ma devirlerini büsbütün kapamak zaruretinde iken yeniden açmakttr." ${ }^{12}$ Hatta o kadar ileri gidilmiştir ki, İstanbul Hükümetleri kendi silahlı birliklerine Millî Mücadele birliklerine saldırma ve onları ortadan kaldırma emrini işgalci devletlerin gönüllerinin de hoşluğunu kazanma ve kendi iktidarlarını koruma gayesiyle vermekten geri durmamıştır. Hatta asayiş sorununu çözmek için Samsun'a gönderilen Mustafa Kemal kısa bir süre sonra asi ve asayişi bozanların lideri olarak görülmüştür.

Özellikle Damat Ferit Hükümetleri tarafından Kuvâ-yı Millîye'yi ortadan kaldırmak için birçok hesap yapılmıştır. İtilaf devletleriyle el ele verilerek yapılan bu hesapların içerisinde belki de en başta geleni asayişsizlik yaratmak olmuştur. Bunun için Kuvâ-yı Millîye karşıtları, Hıristiyanlara tecavüzde bulunulduğu haberlerini yaymak için kendileri

\footnotetext{
23.

"1. Bige Yavuz, Kurtuluş Savaşı Döneminde Türk-Fransiz İlişkileri, Ankara 1994, s. $22-$

${ }^{12}$. Gökbilgin, age, s.143.
}

${ }^{10}$. Belgelerle Mustafa Kemal Atatürk, Ankara 2003, s.5,6,8,9,18,27,28,39,40, 
Hıristiyanlara saldırarak, çeteler kurarak cinayetler, soygunlar yaptırarak ve bütün bunlar Millî teşkilatlara mal edilerek Kuvâ-yı Millîye ortadan kaldırılmaya çalışılmıştır. ${ }^{13}$ Yine bu dönemde İstanbul Hükümetleri tarafından desteklenen, teşvik ve organize edilen iç isyanlar, asayişi bozucu organizasyon olarak yerini almıştır. İsyanlar Eylül 1919'da başlayıp 1920'nin ortalarına kadar devam etmiştir. Millî mücadelecileri ve bunlara katılanları engellemek, hatta ortadan kaldırmak için başlayan bu isyanlarla ${ }^{14}$ bir buçuk yıla yakın bir süre kardeş kardeşi öldürmüş, şehirler, kasabalar, köyler yakılıp yıkılmış, ciddi anlamda bir kaos ve güvensizlik ortamı yaratılmıştır.

Damat Ferit Paşa Hükümetleri nazarında Anadolu'da asayiş ve düzeni bozan iki grup kabul edilmiştir. Bunlardan birincisi Mustafa Kemal'in önderliğindeki Millî Mücadele örgütleri, bir diğeri de gerçekten millî ve manevi duygulardan yoksun insanların her türlü eşkıyalık eylemleri. Yani işgalci devletlerin mensuplarının eylemleri, onlardan güç ve destek alan gayrimüslimlerin yapmış olduğu insanlık dışı zulümleri bu tasnifin dışında kalmış oluyordu.

\section{2- İtilaf Devletleri, Mondros Mütarekesi ve Asayişin İkinci Boyutu}

Birinci Dünya Savaşının temel sebepleri arasında yer alan Osmanlı topraklarının paylaşılma sorunu, savaşın sonucu itibariyle bu fırsatı galip devletlere vermiştir. Dört yıl süren savaşın sonunda imzalanan Mondros Mütarekesi normalde silah bırakışması olarak imzalanmıştı. Ancak içeriği, tamamen silah bırakmadan ziyade bir devleti ve topraklarını tarumar etmek için ne lazımsa onunla doldurulmuştu.

Osmanlı Devletine kabul ettirilen bu mütareke metni sayesinde evvela gelip İstanbul'a yerleşen İtilaf Devletleri, daha sonra Osmanlı topraklarının diğer yerlerini kendi aralarındaki paylaşmaya göre işgal etmişlerdir. İtilaf devletlerinin İstanbul'a yerleşmelerinden, İstanbul'u terk edecekleri 1922 Kasımına kadar dillerinden ve direktiflerinden düşürmedikleri tek bir kelime vardı; o da "asayiş" kelimesiydi. İstanbul Hükümetlerini en fazla baskı ve kontrol altına almada kullandıkları yalan ve iftira jargonunu süsleyen kelime asayiş olmuştur. Tabii İtilaf Devletlerine asayiş konusunda en büyük fırsatı Mondros Mütarekesinin bazı maddeleri vermiştir. Bunları sıralamak gerekirse;

"1. Madde: Çanakkale ve Karadeniz Boğazları'nın açılması ve Karadeniz'e geçis sağlanmast. Çanakkale ve Karadeniz Boğazlart kalelerinin Müttefiklerce işgal edilmesi.

${ }^{13}$.Yücel Özkaya, " Mustafa Kemal”, Tarihi Makaleler, Ankara 2002, s. 163. Cemil Özgül, Heyet-i Temsiliye'nin Ankara'daki Calışmaları ( 27 Aralık 1919- 23 Nisan 1920), Ankara 1989, s. 69

${ }_{14}$. Hazma Eroğlu, Türk Inkulâp Tarihi, İstanbul 1982, s. 206-210. 
5. Madde: Stnırların denetlenmesi ve iç düzenin korunması için gerekli olan birlikler dişında, Türk Ordusunun derhal terhis edilmesi. ( Birliklerin insan gücü ve konuşu daha sonra Türk Hükümeti ile dantşılarak saptanacaktır).

6. Madde: Türk karasularında yada Türkiye'nin işgalindeki sularda bulunan bütün savas gemilerinin teslim edilmesi. Türk karasularında kolluk yada benzeri amaçlar için gerekli görülebilecek bir takım kü̧̈ük gemiler dışında, bu gemilerin belirtilecek Türk limanında yada limanlarında gözaltına alınması.

7. Madde: Müttefikler kendi güvenliklerini tehdit edecek herhangi bir durum ortaya çıkarsa, herhangi bir stratejik noktayl işgal etme hakkı bulunmast.

10. Madde: Toros tünel sisteminin Müttefiklerce işgali.

12. Madde: Türk Hükümetinin haberleşmeleri dişında,bütün telsiz, telgraf ve kablo istasyonlarınin Müttefiklerce denetim altina alınmast.

20. Madde: Beşinci madde gereğince terhis edilecek Türk ordusu bölümünün, taşıtlarını da içermek üzere, araç ve gereçlerinin, silahlarının ve cephanesinin kullanılış biçimi konusunda verilebilecek buyruklarin yerine getirilmesi.

24. Madde: Altı Ermeni ilinde karışıklık çıkarsa Müttefikler bu illerin herhangi bir bölümünü işgal etme hakkını ellerinde tutarlar." ${ }^{15}$

Yukarıdaki maddeler dikkatle değerlendirildiğinde Osmanlı devletinin ve Türk insanının geleceğinin nasıl bir tehdit ve tehlike altına alındığını görmek mümkündür. Bir devletin ordusu terhis ettirilmiş, onu her türlü tehlike ve tehditten koruyacak, huzur ve asayişini saglayacak olan silahlı güçten yoksun bıraktırılmış, topu, tüfeği, donanması cephanesi teslim alınmış, haberleşme ve ulaşım ağı kontrol edilmeye başlanmış, başkenti ele geçirilmiş, ülkenin diģer geri kalan yerlerini de işgal etmek için, kendilerince içi doldurulan asayiş ve emniyet tehlikesine bağlı kılınmış, Yunanlılara haydi İzmir ve çevresini sana verdik denilmiş ve koruyuculukları altında İzmir Körfezine getirilmiş, sonra da, işgalci itilaf devletleri bu ülkede asayiş bozuk, kendimizi güvende hissetmiyoruz diye feveran koparmıştır. İşte Mondros Mütarekesi sonrası İtilaf Devletlerinin yapmış olduğu şey, bu olmuştur.

Mütarekeden ve İtilaf Devletlerinden güç alarak ilk önce harekete geçen, Rumlar ve Ermeniler olmuştur. Bu dönem, gayrimüslimlerin her türlü asayişi bozan eylemleri ile doludur. Mesela, 20 Şubat 1919

15. Seha L. Meray - Osman Olcay, Osmanlı Imparatorluğu'nun Çöküş Belgeleri, Ankara 1977, s. 1-5. 
Perşembe günü Mersin bölgesinde Ermeni çeteleri Tece Köyünü ateşe vermiş, köyde toplu katliam ve yağma yapmışlardır. Ege, Marmara ve Trakya'da Türk köylerini basan Rum çetelerinden birisi, Bostancı'da dışişleri memurlarından Esat Beyle Nidai Bey'i öldürmüşlerdir. Batum'dan gelip Giresun yakınlarında karaya çıkan bir Rum çetesi ordu birlikleri tarafından yok edilmiştir. ${ }^{16} 1919$ 'un Mart ayı itibariyle Rum çetelerinin değişik yerlerde faaliyetleri her geçen gün artmıştır. Söke'nin Kelih köyünde âşâr ambarlarındaki zahire, Rum köylüler tarafından yağma edilmiş, hükümetten de hiç korkmadıklarını özellikle bildirmişlerdir. Tomatca Köyüne Yunan askeri elbisesi giyip gelen Rum asker kaçakları çetecilik yapmış, pusuya düşürdükleri insanları öldürmüşlerdir. Cenazelere sahip bile çıkılamamıştır. İzmir bölgesinde, Ayvalık ve Urla'da seri halinde cinayetler işlenmiştir. Bornova'nın Işıklar Köyü yakınlarında bir jandarma müfrezesi Rum eşkıyasının pususuna uğramış; olayı jandarmanın Rumlara saldırısı şeklinde göstermek için hazırladıkları şikâyetlerini heyetle İngiliz ve Fransız temsilcilere ulaştırmışlardır. İstanbul'da 16 Mart'ta Büyükada, Arnavutköy, Kumkapı, Yanikapı ve diğer birçok yerde Rumlar gösteriler yapmışlardır. Nisan ayı başlarında Rum eşkıya Kartal, Pendik ve buralara bağlı köylerde cinayetler işlemiş; hayvanlarını otlatan bir Türk kızını dağa kaldırmış, 14 yaşlarında İsmail adında bir çocuğu on beş yerinden, 12 yaşında Mustafa adında bir diğer çocuğu on sekiz yerinden, 10 yaşında İsmail adlı çocuğu ise dört yerinden bıçaklayıp parçalayarak menfurca öldürülmüşlerdir. ${ }^{17}$

İtilaf Devletlerinin her türlü destek ve kayırması ile asayişin bozulmasına neden olan gelişmelerden biri de Sivas'ın Gümüşhacıköy kazasına bağlı Karaköy'de yaşanmıştır. Köy halkından olan Vangal adındaki bir kişinin başkanlığındaki 18 kişilik çetenin yakalanması için Çorum'dan yardım istenmiş; ancak, Çorum'dan hareket eden birliğin iki İngiliz subay tarafından engellendiği Ankara Valisi Muhiddin Bey tarafından 3 Haziran 1919 tarihli şifre telgrafla İçişleri Bakanlığına bildirilmiştir. $^{18}$ İşgalci devletler bir taraftan asayişin bozulması için çalışırken, diğer taraftan da bunu önlemeye çalışan güvenlik güçlerini engellemişlerdir.

Bir diğer örnek gelişme de İçişleri Bakanlığından Canik (Samsun) Mutasarrıflığına gayet önemli ve acele şifresiyle gönderilen yazıda görülmektedir. İlgili yazıda; Yunanlıların Kordos Koyu tarafına Samsun'da ihtilâl çıkarmak ve bölgenin asayişini bozulmuş göstermek amacıyla 350 erkek, 70 kadından oluşan bir fedai grubunun

\footnotetext{
16. Sarihan, age, s.139,156,163,378.

${ }^{17}$. Gökbilgin, age, s. 58-61.

${ }^{18}$. BOA, DH.EUM .AYŞ, 11/99, T.C. Devlet Arşivleri Genel Müdürlüğü, age, s. 28.
} 
gönderileceği haberinin alındığı ve gerekli tedbirlerin alınması istenmiştir. ${ }^{19}$ Yine buna benzer bir gelişme Batı Anadolu'da yaşanmıştır. Jandarma Genel Komutanlığından Manisa, Aydın, Denizli, Karesi Mutasarrıflıklarına gönderilen 17 Haziran 1919 tarihli yazıda; Yunan ordusu tarafından boşaltılmakta olan İzmir ve çevresinde devamlı asayişi bozmak ve Yunan davasına zemin hazırlamak için teşkilat oluşturmak amaciyla "Buzat Hakkı" adlı bir komitenin sevk ve idaresi altında Romanya vapuruyla 130 çete reisinin İzmir'e sevk edildiği ve bu teșkilatın amacının asayişi ihlâl ederek siyasî menfaat temin etmek olduğu bildirilerek gerekli takibin yapılması istenmiştir. ${ }^{20}$ Hatta o kadar ileri gidilmiştir ki, Rum çeteleri Müslüman kıyafetleri giyerek Türk köylerine saldırarak soygun ve katliam yapmışlardır. ${ }^{21}$ Böylece hem asayişin olmadığı havası yaratılmış, hem de asayişin Türk çeteler tarafından bozulduğu kanaatini oluşturarak İtilaf Devletleri harekete geçirilmiştir. Yine aynı mantık ve amaçla Doğu Trakya'da Yunan ve Rum tahrikleri görülmüştür. Hıristiyan halk asayişin olmadı̆̆ını göstermek için, evlerinin pencerelerinden akşamdan sabaha kadar silah atmışlardır. Hatta bu işlerine, kandırdıkları saf Müslümanları da katmışlardır. ${ }^{22}$

İtilaf Devletleri Mondros Mütarekesine yazdıkları maddelere işlerlik kazandırmak için, bir taraftan gayrimüslimlerin kurmuş oldukları örgütleri ve bunların çetelerini her türlü malzeme bakımından destekleyip teşvik ederken, diğer taraftan ülke genelinde asayişi bozucu bu eylemleri yapanların kovuşturulmamasını, yakalananların serbest bırakılmasını sağlamış ya da bunların kaçmasına yardımcı olmuşlardır. Millî Savunma Bakanlığının İçişleri Bakanlığına 23 Mart 1919 tarihli gönderdiği yazısında, “ ..Cinayetleri yapanlar hakkında takibat yapılmasına itilaf temsilcileri mani oldukça asayişin korunmasının.."23 imkânsız olduğunu bildirmiştir.

Yukarıdaki örneklerden de anlaşılacağı gibi, mütareke metni, İtilaf Devletlerine Osmanlı topraklarını her türlü kontrol etme fırsatı tanırken, aynı zamanda ülkenin ve milletin güven, huzur ve bağımsızlığını tehdit edecek her türlü asayişsizliğin kapısını aralayacak imkanı da vermiştir.

O zaman ikinci boyutuyla asayişi şekillendiren temel argümanın, Mondros Mütarekesi ve onun hem içini dolduran taraf olarak, hem de

${ }^{19}$. BOA, DH. SFR, 16 N 337, 100/117.

${ }^{20}$. BOA, DH.ŞFR, 18 N 337, 100/136.

${ }^{21}$. Mustafa Turan, Yunan Mezalimi, Ankara 1999, s. 17.

22. Zekai Güner, Trakya-Paşaeli Müdafaa-i Hukuk Cemiyeti'nin Kuruluşu ve Faaliyetleri, Ankara 1998, s. 105. 2007 , s. 84 .

Zafer Çakmak, Izmir ve Çevresinde Yunan Isgali ve Rum Mezalimi, İstanbul 
yorumunu yapan taraf olarak asayiş konusunda baskı ve kendini haklı göstermeye çalışan İtilaf Devletlerinin bizzat kendisi ortaya çıkmaktadır. İtilaf temsilcileri asayiş konusunda şikâyetlerini dile getirirken azılıkların yaptıklarını hiç bir zaman söz konusu etmemişler; tam tersine, gayrimüslimlerin ve işgalci devletlerin kendi mensuplarının Türkler tarafından can ve mal emniyetlerinin tehdit edildiğini ısrarla vurgulamışlardır. Özellikle Kuvâ-yı Millîye birlikleri ve mensupları, bu şikâyetlerde en öncelikli sırayı almıştır.

\section{Kuvâ-yı Millîye ve Asayişin Üçüncü Boyutu}

Mondros Mütarekesi imza edilir edilmez İtilaf Devletlerinin ilk işi 25 maddelik metnin hemen uygulamasına geçmek olmuştur. Uygulama aşamalı olarak gerçekleştirildikçe Türk insanının dört yıllık savaş çilesinin bitmesinin oluşturduğu ümitleri yavaş yavaş yıkılmaya başlamıştır. Başta İstanbul olmak üzere Anadolu'nun hemen hemen her yerinde gayrimüslimlerin sevinç, heyecan ve coşkusunun yanı sıra önceden kurmuş oldukları silahlı örgütlerin faaliyete geçmesi ile rahat ve huzurun bozulacağı anlaşılmaya başlamıştır. Ancak Türk halkını ciddi anlamda harekete geçiren, şehir, kasaba ve köylerin işgal edilmeye başlaması olmuştur. Özellikle Paris'te ABD, İngiltere, Fransa, Japonya ve İtalya'nın katıldığı 18 Ocak 1919'da başlayan Paris Barış

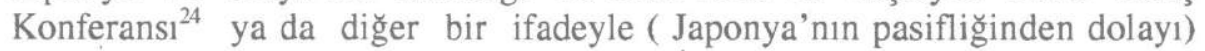
Dörtler Konferansında Yunanistan'a İzmir ve çevresinin verilme kararıyla 15 Mayıs 1919 'da İzmir'in işgal edilmesi, ${ }^{25}$ ilk önce bu bölgede olmak üzere her yerde silahlı direniş hareketi boy göstermeye başlamıştır. İşgaller karşısında Türk halkının vatan, namus ve canını korumak için bir araya gelerek oluşturduğu bu birlikteliğe "Millî Kuvvetler" anlamina gelen "Kuvâ-yı Millîye" denilmiştir.

Başta her millî gücün kendi kendine örgütlenip hareket ettiģi bir süreç yaşanmıştır; fakat daha sonra bu güç, Mustafa Kemal'in liderliğinde düzenli, disiplinli ve tek bir merkezden yönetilir hale getirilmiştir. Bağımsızlık mücadelesinin her bir hareketi o günün en moda deyimi olarak tarihe geçen asayiş kelimesi ile anılarak, düzeni bozan, huzuru kaçıran taraf olarak görülmüştür. Damat Ferit Paşa Hükümetleri ve İtilaf Devletlerinin bu dönemde en fazla yollarının kesiştiği, birlikte anlaşarak hareket ettikleri durum Millî kuvvetlerin "asayişi bozan" olarak kabul edilmesi olmuştur. Aslında işgal ve direnişin gerçekleştiği bu dönemde Türk insanının kurmuş olduğu bu örgütlerin içinde hoş olmayan insanî olmayan tavırlar sergileyenler

\footnotetext{
${ }^{24}$. Fahir Armaoğlu, 20.Yüz Yul Siyasi Tarihi 1914-1980, Ankara 1987, s. 145

25. Izzet Öztoprak, Londra Konferansı ve Türkiye Meselesinin Ceryan-1 Müzakeratı, Atatürk Dönemi Türk Dış Politikası, Ankara 2000, s. 167.
} 
görülmüştür; ancak bütün bir direnişi bu şekilde değerlendirmek doğru olmasa gerek.

Yukarıda da belirtildiği gibi Mustafa Kemal'in Samsun'a gönderilmesinin temelindeki önemli konulardan biri olarak İtilaf Devletlerinin asayişin bozulduğu şikâyetlerinden kaynaklandığı bilinmektedir. Bu işe oldukça önem veren Mustafa Kemal daha Samsun'a varmadan yerel yönetici ve komutanlardan konuyla ilgili bilgi almaya çalışmıştır. Sivas Valiliğine, Canik Mutasarrıflığına ve III. Kolordu Komutanlığı'na gönderdiği acele şifre yazı ile; Sivas ve Canik (Samsun) bölgelerinde faaliyette bulunan eşkıya çetelerinin İslâm, Gürcü, Rum ve Ermeni olduklarının bilindiğini; ancak bunların sayılarının ve hangi bölgede etkin olduklarının, hangi tür silah kullandıklarının ve ne zamandan beri eşkiyalık yaptıklarının, bu çetelerin içerden mi yoksa dışardan mı geldiklerinin tespit edilip acilen Kolordu Komutanı Selâhaddin Bey tarafından Samsun'da kendisine bilgi verilmesini istemiştir. ${ }^{26}$ Yine aynı hassasiyetle hareket eden Mustafa Kemal, İstanbul'a gönderdiø̆i telgrafta; Samsun ve Amasya çevresindeki jandarmaların asayişi sağlamaları ve sürdürmeleri için bölge halkından bir miktar insanın silah altına alınması için izin istemiştir. ${ }^{27} 11$ Haziran 1919 tarihli İstanbul'a gönderdiği bir başka yazıda ise; Bafra'daki İslâm çetelerinin bir kısmının aman dileyerek sığındıkları, bir kısmının ise dağılarak faaliyetine son verdiklerini, Samsun'da kasaba dışında batı bölgesinde 12 kişilik bir Kürt çetesinden başka Müslüman çetesi kalmadığını bildirmiştir. ${ }^{28}$

Mustafa Kemal Havza'dan İstanbul'a gönderdiği genel vaziyet hakkındaki oldukça teferruatlı yazısında durumu şöyle dile getirmiştir: “Anlaşıllyor ki Rumlar nisbetsiz derecedeki azlıklarına rağmen, Sivas vilâyetnin Amasya ve Tokat Sancaklarında da ayni Canik livasindaki gibi çetecilik ve siyasî emeller teşkilâtını tatbik ve idare ediyorlar. Bugün bilhassa Canik hududunda olmak itibariyle Amasya livast dahilinde 21 Rum çetesi görünmektedir. Bunların reisleri ve faaliyet mıntıkaları bilinmektedir.... Hıristiyan unsurları sılmartıp çılgınca vaziyetlere sokan Rum ve Ermeni kundakçıları âsayişi ecnebilere karşı bozuk göstermek ve işgal ve müdahaleleri celb eylemek ve bilhassa ecnebi zabitleri olan yerlerde hükûmetle hiç temas etmemek ve doğruca ecnebilere müracaat etmek gibi işleri ve İslâmları aleyhine vakalar meydana getirmek gibi tavir ve hareketleri devam ettiriyorlar." 29

${ }^{26}$. BOA, DH.SFR, 99/137, Belgelerle Mustafa kemal Atatürk, s.5-6.

27. BOA, MV, 215/132, Belgelerle Mustafa Kemal Atatürk, s. 18.

28. BOA, DH.KMS, 53-2/74_4-5, Belgelerle Mustafa Kemal Atatürk, s. 39-40.

${ }^{29}$. Gökbilgin, age, s. 139. 
Memlekette asayişin sağlanmasında bu kadar hassas olduğunu gösteren Mustafa Kemal ne yazık ki kısa bir süre sonra eşkıyalarla aynı kefeye koyulmuştur. Samsun'a çıktığı günden beri onu takip eden İngiliz yetkililer ondan şüphelenmiş ve hatta İngilizlerin Karadeniz Ordusu Başkomutanı General Milne Harbiye Nezaretine gönderdiği yazıda Mustafa Kemal ve kurmay heyetinin İstanbul'a çağrılmasını gerektiğini yazmıştır. Ondan sonra İstanbul'daki İngiliz yetkili Amiral Calthorpe Osmanlı Dışişlerine verdiği notada, "Bazl kötü niyetli kimselerin hadise çıkarmaya çalıştıklarını ve bu işte Mustafa Kemal'in baş rolü oynadığını..” yazarak, General Milne'nin yazısını da hatırlatarak, gelişmelerden hükümet yetkililerini sorumlu tutulacaklarını bildirmiştir. ${ }^{30} \mathrm{Bu}$ gelişmelerin yaşandığ 1 Haziran günü Harbiye Nezâreti Mustafa Kemal'i geri çağırmıştır.

"Millî Mücadele" adlı eserinde Kâzım Özalp, Batı Anadolu'da bir taraftan Millî Mücadele ile ilgili çalışma ve hizmetleri, Yunan işgaline karşı direnişi nasıl örgütleyip mücadele ettiklerini anlatırken diğer taraftan eşkıya çetelerinin neler yaptığını ve onlara karşı nasıl bir uğraş verdiklerini de yazmaktadır. Örneğin, 22 Haziran 1919'da Yunan birliklerinin taarruzuna karşı yaptıkları mücadeleyi ve geri çekilip Susurluk yakınlarında geceyi geçirirlerken; Çerkez Davut ve adamlarının Kirmasti yolu üzerine çıkarak halkı, askerleri ve memurları soydukları, çok feci cinayetler işledikleri haberinin kendilerine ulaştığını anlatmaktadır. ${ }^{31}$ Millî Mücadelecilerin asayişe bakışları ya da eşkıya ve çetecilere bakışları böyle olmuştur. Bir taraftan işgallere karşı koyarlarken diğer taraftan gayri ahlaki olayların icracılarına karşıda mücadele etmişlerdir.

Mustafa Kemal askerlik görevinden istifa edip, millî mücadele hareketinin önderliğini yürüttüğü sürede de asayiş konusunda aynı hassasiyeti göstermeye devam etmiştir. Türkiye Büyük Millet Meclisi başkanı olarak 25/26 Ağustos 1920 tarihli asayiş beyânnâmesinde bunu görmek mümkündür. Kaza ve nahiyelerin yetkili memurlarına, belediye ve Müdafaa-i Hukuk derneklerinin başkanlarına, askeri yetkililere gönderdiği beyânnâmede; hiç kimsenin hiçbir sebeple yani Ankara Hükümetinin haberi olmadan kuvvet toplamaya yetkisi olmadı̆̆ tarihten önce böyle bir girişimde bulunmalarının amaçlarının ne olduğu konusunda kendisine bilgi vermelerini, aksi durumun ülke genelinde asayişi ihlâl etmekten, TBMM'ye zarar ve ülke insanını iğfal suçlarıyla yargılanacakları bildirilmiştir. ${ }^{32} \mathrm{Bu}$ beyanname aynı zamanda Ankara

${ }^{30}$. Selahattin Tansel, Mondros'tan Mudanya'ya Kadar, İstanbul 1991, s. 1-3.

31. Kazım Özalp, Millî Mücadele 1919-1922 I, Ankara 1985, s. 142.

32. Zekai Güner, Orhan Kabatas, Milli Mücadele Dönemi Beyânnâmeleri ve Basınt, Ankara 1990, s. 20. 
Hükümetinin Anadolu'nun asayişinden sorumlu olduğunu ortaya koyması bakımından da önemlidir.

Mütareke döneminin üç boyutlu asayiş anlayışının bu üçüncü boyutu olan Millî Mücadelecilerin ve onun lideri Mustafa Kemal'in asayiş anlayışının diğer ikisinden çok farklı olduğu anlaşılmaktadır. Mustafa Kemal'e, Kuvvâcılara veya millî mücadelecilere göre asayişi bozanların, gayrimüslimlerin hareket ve örgütlerinin eylemleri, itilaf devletlerinin işgalleri, İstanbul Hükümetlerinin bu iki grubu görmezden gelerek yapmış olduğu icraatlar ve özellikle Millî Mücadeleye karşı kullandığ ${ }_{1}$ Hilafet Ordusu, Kuvâ-yı İnzibatiye gibi güçlerle kardeşi kardeşe vurdurma girişimleri olarak kabul edilmiştir.

\section{SONUÇ}

Mondros Mütarekesi'nin imzalanması ve yürürlüge girmesi ile beraber, Osmanlı coğrafyasında insanların her türlü emniyet ve güvenini tehdit eden bir dönem başlamıştır. Dönemin en popüler kavramı olan "asayiş", hemen hemen herkesin ağzından düşürmediği, resmi ya da gayrî resmi her evrakın ortak ifadesi olmuştur. Bu kavramın aynı zamanda üç ayrı boyutta anlama, algılama ve değerlendirmesinin yapıldığına da döneme ait arşiv belgelerinde ve yapılan araştırmalarda şahit olmak mümkündür.

Üç boyutlu asayiş anlama, algılama ve değerlendirmesinin birinci ve resmi tarafı ve sorumlusu olarak İstanbul hükümetleri; asayişin sağlanması için askerî ve sivil bütün yetkililerin görevlerini yapmaları ve gerekli tedbirleri almaları konusunda gerekli emirleri vermeye çalışmıştır. Ancak ilerleyen zaman içerisinde özellikle gayrimüslimlerin yapmış olduğu huzur ve güveni bozan eylemleri karşısında, İtilaf Devletlerinin koruma ve kollamalarının da etkisinde kalarak tarafgir davranmaya başlamıştır. Özellikle Kuvâ-yı Millîye hareketinin doğuşu ile birlikte artık, İstanbul Hükümetleri içerisinde başta Damat Ferit Paşa hükümetleri için asayişi bozan huzuru kaçıranların bunlar oldugu inanc1 ile hareket edildiği görülmüştür. Yani gayrimüslimler devreden çıkarken, diğer çeteciler ve Millî mücadeleciler asayişi bozan olarak görülmüş ve hiç çekinmeden üstlerine gidilmiştir. Özellikle Millî Mücadelenin engellenmesi için işgal devletleriyle ortak hareket etmekten de asla çekinilmemiştir.

İtilaf devletlerinin diğer bir ifadeyle işgal devletlerinin de bir asayiş anlayışı ve uygulaması olduğu bu süreçte görülmektedir. Özellikle Mondros Mütarekesi'nin bu anlayışı şekillendirdiğini söylemek yanlış olmasa gerek. İtilaf Devletleri Türk topraklarında planlarını gerçekleştirmek için ilk adım olarak Mondros Mütarekesi'ni hazırlamış oldukları görülmektedir. Kendi aralarında yapmış oldukları paylaşımı, 
Rum ve Ermenilere vaat ettikleri devletlerini kurma girişimlerini gerçekleştirmelerine engel olabilecek her türlü girişimi, asayişi bozucu faaliyet olarak yorumlamışlardır. Türk milletinin can, namus ve bağımsızlığını korumak ve kurtarmak için yapmış olduğu her türlü örgütlenme ve girişim işgal devletleri nazarında asayişi bozan, huzuru kaçıran gelişmeler olarak değerlendirilmiștir. Mütareke ile birlikte Anadolu'daki gayrimüslimlerin başlatmış oldukları her türlü saldırı, yol kesme, cinayet, hırsızlık, ırz ve namus çiğneme ve benzeri eylemleri görmezden gelinmiş hatta korunmuştur. Osmanlı Devlet yetkilileri bu durumdan çok şikâyetçi olmalarına rağmen İstanbul Hükümetlerinin işgal devletlerinin tavırlarını dikkate aldıkları için çok da görevlerini yapamamışlardır. O günün ifadesiyle, Müslümanların kurmuş oldukları çetelerin haklı ya da haksız her faaliyetleri özellikle gayrimüslimlerin yapmış oldukları karşısında gösterdikleri tepkiler İstanbul Hükümetlerine şikâyet edilmiştir. Önlemler alınmadığı takdirde işgal edilmeyen yerlerin de işgal edileceği tehdidi yapılmıştır. Bu arada gelişen Millî Mücadele hareketi, başta İşgal Devletleri olmak üzere Damat Ferit Paşa Hükümetleri tarafından asayişi bozan çok büyük bir tehlike olarak algılanmış ve ortak hareket edilerek engellenmeye çalışılmışırı. Hatta bu arada İşgal Devletleri Kürt aşiretleri üzerinde de yapmış oldukları gizli girişimlerle Millî Mücadele karşıtı harekete geçmelerini arzulamışlardır. Kısaca Türk insanının en doğal hakkı olan bağımsız yaşama hakkı için yapıp ettikleri asayişi bozan tehlikeler olarak görülürken, gayrimüslimlerin, kendilerinin ve desteklediklerinin yapmış oldukları eylemler, hiçbir şekilde asayişi tehlikeye sokan girişimler olarak değerlendirilmemiştir.

Kuvâ-y1 Millîye hareketi örgütlenmesi ve bunun yönetici kadrolarının asayiş konusuna yaklaşımları ise diǧer iki yaklaşımdan farklı olduğu da bir gerçektir. Her şeyden önce bu millî refleks savaş ve sonrası ortamı fırsat bilen gayri meşru her türlü çetecilik olayını kendisinden bildikleri de dahil olmak üzere, karşı çıkmış ve engellemeye çalışmıştır. Yani yol kesen, cana kast eden, baskın yapıp yakıp yıkan, zorla ihtiyaçlarını halktan gidermeye çalışan kim olursa olsun karşı çıkılmıştır. Zaten ilerleyen zaman içerisinde Mustafa Kemal'in liderliği ile bu hareket daha disiplinli, kural ve kaideleri olan merkezî bir duruma getirilmiştir. Bu hareket için asayişi bozanlar; gayrimüslimler, İ̧̧gal Devletleri ve onlarla beraber hareket eden Damat Ferit Paşa Hükümetlerinin uygulamaları olarak görülmüştür.

Mütareke süresince "asayiş" en çok Türk milletini mağdur etmiş ve özellikle Millî Mücadele hareketi ve onun önderini ise ağzı açık makas misali iki taraflı tehlike ve zorlukla karşı karşıya koymuştur. 


\section{KAYNAKÇA}

Osmanll Arşivi:

BOA, DH.ŞFR, 337 N 16. $100 / 109$

BOA. DH.ŞFR, 337 N 19, $100 / 148$.

BOA, DH. ŞFR, 16 N 337, 100/117.

BOA, DH.ŞFR, 18 N 337, 100/136.

\section{Kitap ve Makaleler}

AYDINEL, Sıtkı, Güney Batı Anadolu'da Kuvâ-yı Mlliye Harekâtı,Kültür Bakanlı̨̆ Yayınları, Ankara,1993.

APAK, Rahmi, İstiklâl Savaşında Garp Cephesi Nasıl Kuruldu, Türk Tarih Kurumu Basımevi,Ankara,1990

ARMAOĞLU, Fahir, 20.Yüz Yıl Siyasi Tarihi 1914-1980, Türkiye İş Bankası Yayınları, Ankara 1987.

ÇAKMAK, Zafer , İzmir ve Çevresinde Yunan İsgali v Rum Mezalimi,Yeditepe Yayınevi, İstanbul, 2007.

EROĞLU, Hazma, Türk İnkılâp Tarihi, Millî Eğitim Basımevi,İstanbul 1982.

GÖKBİLGIN, Tayyib, Millî Mücadele Başlarken, Türk Tarih Kurumu Basımevi, Ankara, 1959.

GÜNER, Zekâi, Trakya-Paşaeli Müdafaa-i Hukuk Cemiyeti'nin Kuruluşu ve Faaliyetleri,Atatürk Araştırma Merkezi Yayınları, Ankara 1998.

GÜNER, Zekâi, KABATAŞ Orhan, Millî Mücadele Dönemi Beyânnâmeleri ve Basını, Atatürk Kültür Merkezi Yayınları, Ankara, 1990.

JAESCHKE, Gotthard, Kurtuluş Savaşı İle İlgili İngiliz Belgeleri, Türk Tarih Kurumu Basımevi, Ankara,1991.

JAESCHKE, Gorthard, Türk Kurtuluş Savaşl Kronolojisi - Mondros'tan Mudanya'ya Kadar, Türk Tarih Kurumu Yayınları,Ankara,1989.

MERAY, Seha L.,OLCAY Osman, Osmanlı İmparatorluğunun Çöküş belgeleri, Ankara Üniversitesi Siyasal Bilgiler Fakültesi Yayınları, No: 409, Ankara, 1977.

ÖZALP, Kâzım, Millî Mücadele 1919-1922 I, Türk Tarih Kurumu Basımevi, Ankara, 1985.

ÖZGÜL, Cemil, Heyet-i Temsiliye'nin Ankara'daki Çalışmalarl ( 27 Aralık 191923 Nisan 1920), Atatürk Araştırma Merkezi Yayınları, Ankara,1989. 
ÖZKAYA, Yücel, “ Mustafa Kemal”, Millî Mücadele Tarihi Makaleler, Atatürk Araştırma Merkezi Yayınları, Ankara, 2002.

ÖZTOPRAK, İzzet, Londra Konferansı ve Türkiye Meselesinin Ceryan-1 Müzakeratı, Atatürk Dönemi Türk Dış Politikası, Atatürk Araştırma Merkezi Yayınları, Ankara ,2000.

SONYEL, Dr. Salahi R., Türk Kurtuluş Savaşı ve Dış politika I,Türk Tarih Kurumu Yayınları, Ankara, 1995.

SARIHAN,Zeki,Kurtuluş Savaşı Günlügü I,Türk Tarih Kurumu Yayınları,Ankara 1993.

TANSEL, Selahattin, Mondros'tan Mudanya'ya Kadar, Cilt I, Millî Eğitim Bakanlığı Yayınlanı, İstanbul, 1991.

TURAN, Mustafa, Yunan Mezalimi,Atatürk Araştırma Merkezi Yayınları, Ankara,1999.

YAVUZ, Bige, Kurtuluş Savaşı Döneminde Türk - Fransız Illişkileri, Türk Tarih Kurumu Yayınları,Ankara, 1994.

Belgelerle Mustafa Kemal Atatürk ( 1916-1922), T.C. Başbakanlık Devlet Arşivleri Genel Müdürlügü, Osmanlı Arşivi Dairesi Yayınları , Ankara, 2003. 